\title{
Fact Sbeet
}

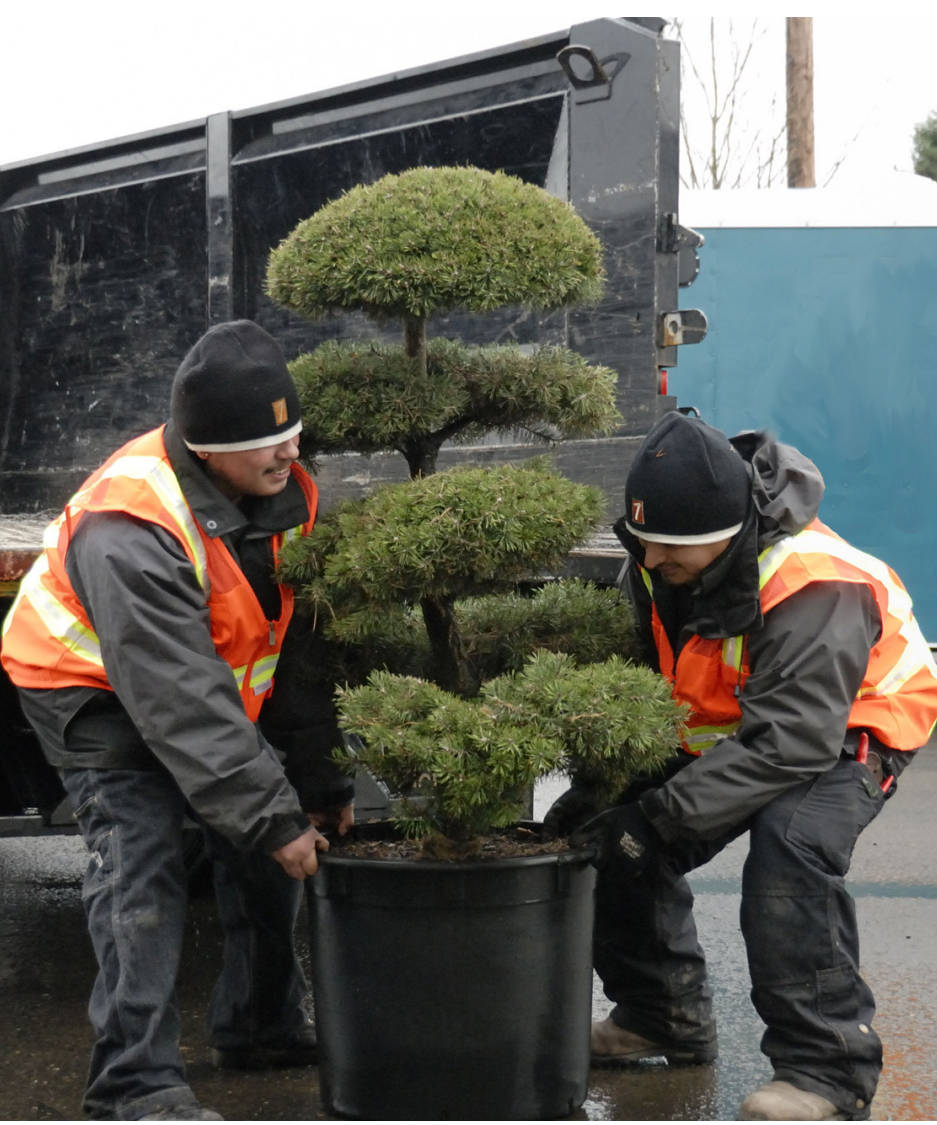

Working in teams can reduce the risks of occupational injuries and fatalities, Photograph courtesy of John Curtis

\section{Overview}

An average of 197 landscape services workers ${ }^{1}$ died from on-the-job injuries each year between 2003 and $2006^{2}$. The fatality rate for the landscape services industry, about 25 deaths per 100,000 workers, is similar to that for more recognized high-risk industries such as agriculture and mining. Although landscape services workers make up $0.8 \%$ of the U.S. workforce, they experienced $3.5 \%$ of the total occupational fatalities.

Landscape services workers complete jobs such as landscape and irrigation installation, lawn care, tree removal, general landscape maintenance and snow removal.

\section{FATAL INJURIES AMONG LANDSCAPE SERVICES WORKERS}

\section{Workforce}

Landscape services workers numbered slightly more than 1 million workers in the U.S in 2006. The Bureau of Labor Statistics (BLS), U.S. Department of Labor, estimated over 924,000 landscaping and groundskeeping workers plus 110,000 first-line supervisors for those workers across all industries. The landscape services industry employed approximately 680,000 workers in 2006 . The remaining $300,000+$ landscape services workers were employed in other industries such as golf courses, resorts, public parks, and schools. Forty-one percent of landscape services workers in 2006 were Hispanic or Latino in comparison with $16 \%$ of the total U.S. workforce. (www.bls.gov/cps/cpsaat11.pdf)

\section{Occupational Fatalities}

BLS Census of Fatal Occupational Injuries (CFOI) identified 789 deaths due to traumatic injuries among landscape services workers and their first-line supervisors between 2003 and 2006. In each of these years, 25 to $30 \%$ of these workers who died were identified as selfemployed. About $56 \%$ of the fatalities occurred among white workers, 29\% among Hispanic and Latino workers and $11 \%$ among Black or African American workers. (http://www.bls.gov/ iif/oshcfoi1.htm) Nearly $80 \%$ of the landscape services worker fatalities occurred in the landscape services industry.

The most common event resulting in landscape services worker fatalities was transportation incidents (Figure 1). About 33\% of all landscape worker fatalities were due to transportation

Mention of any company or product does not constitute endorsement by the National Institute for Occupational Safety and Health (NIOSH). In addition, citations to Web sites external to NIOSH do not constitute NIOSH endorsement of the sponsoring organizations or their programs or products. Furthermore, NIOSH is not responsible for the content of these Web sites.
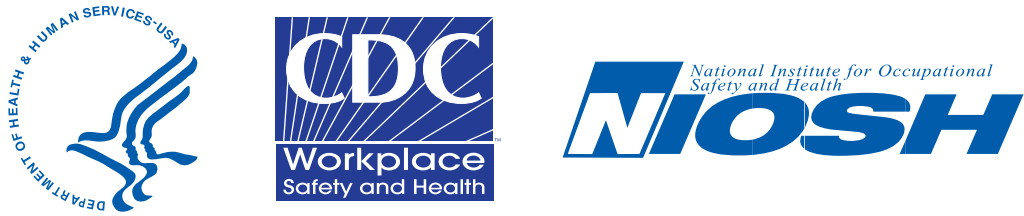


\section{LANDSCAPE SERVICES WORKERS}

Figure 1. Events associated with Landscape Services Worker Fatalities, 2003 - 2006

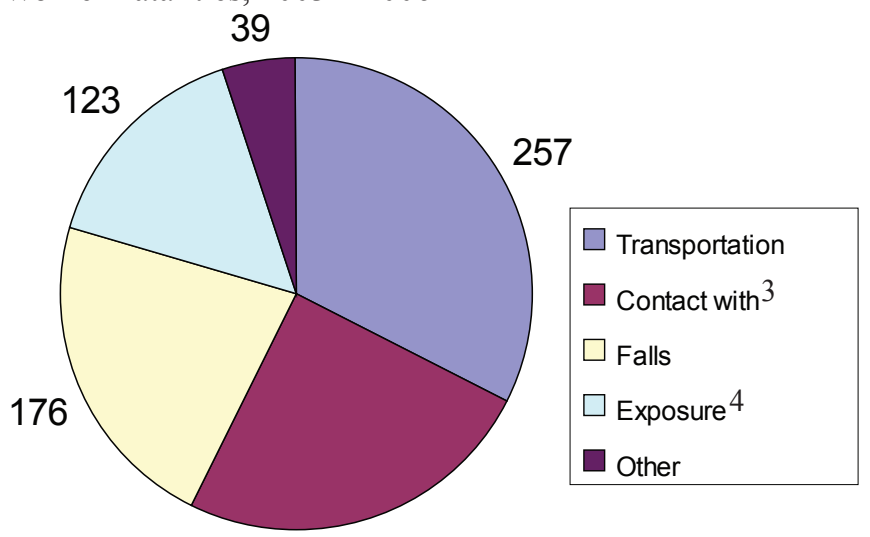

194

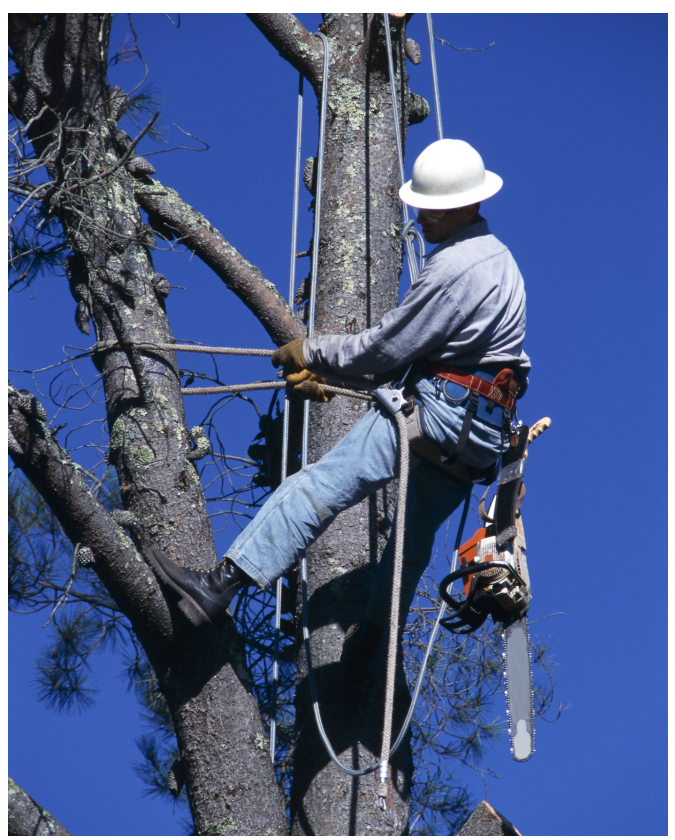

Careful harnessing reduces the risks of fatalities due to falls, Photograph courtesy of Jupiter Images.

Table 1. Activities at the Time of Landscape Services Worker Fatalities, 2003 - 2006

\begin{tabular}{|c|c|}
\hline Activity & Fatalities \\
\hline $\begin{array}{c}\text { Using/Operating Tools or Machinery } \\
\text { (during trimming or removing trees) }\end{array}$ & 355 \\
\hline Vehicle or Transportation Operations & $288)$ \\
\hline Constructing, Repairing, Cleaning & 103 \\
\hline Physical Activity, n.e.c. & 46 \\
\hline Other Activities & 44 \\
\hline
\end{tabular}

incidents in comparison with $43 \%$ for all U.S. industry. Landscape services workers were more likely to die due to falls to lower level, struck by falling objects, and electrocutions $(22 \%, 17 \%$, and $9.8 \%$, respectively) than the overall U.S. workforce $(12 \%, 6.3 \%$, and $4.4 \%$ respectively).

Landscape services workers were engaged in a range of activities at the time of the occupational fatalities (Table 1). Using tools or machinery during tree trimming or removal activities was particularly hazardous. Fatalities during tree trimming or removal activities were caused by falls from heights, being struck by falling objects and electrocutions. Information is not available to determine if the workers trimming or removing trees were employed by tree services companies or other landscaping services companies. Most landscape services worker fatalities occurred on private property with the largest proportion at private residences (Figure 2). Decentralized job sites, like those listed for these fatalities, are associated with reduced organizational and infrastructure support for safe and healthful work practices.
Figure 2. Locations where landscape services worker fatalities occurred, $2003-2006$.

\section{5}

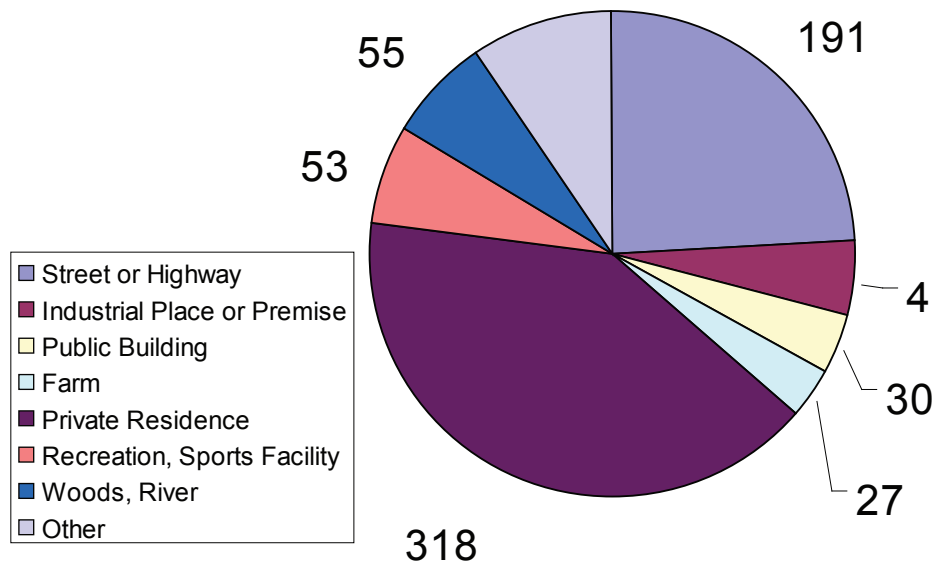




\section{LANDSCAPE SERVICES \\ WORKERS}

Transportation-related fatalities for landscape services workers and their first-line supervisors for 2003-2006 are compared with total fatalities by month in Figure 3 . The numbers of total and transportation related fatalities were generally greater in May through September than in the remaining months.

Figure 3. Numbers of total and transportation-related fatalities among Landscape Services workers and First-Line Supervisors, by month, for $2003-2006$

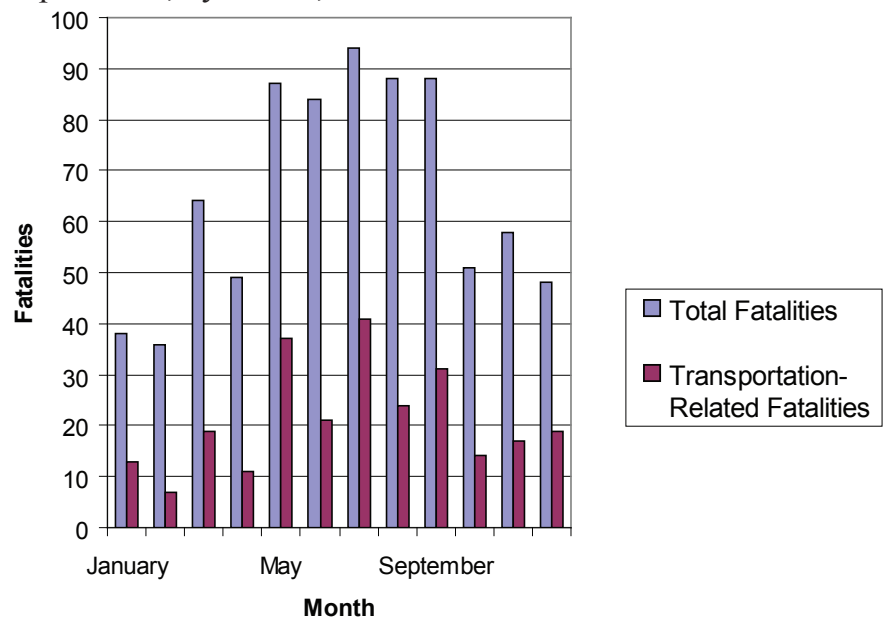

Endnotes

1. Landscape services workers includes these Standard Occupational Classifications: Landscaping and Groundskeeping Workers (37-3011), Tree Trimmers and Pruners (37-3013), Grounds Maintenance Workers, All Other (37-3019), and First-Line Supervisors/Managers of Landscaping, Lawn Service, and Groundskeeping Workers (37-1012).

2. The Census of Fatal Occupational Injuries preliminary data for 2006 were used for the analysis included in this document. The final 2006 data identified four more landscape services worker fatalities.

3. Contact with objects or equipment includes struck by, struck against, and caught in or compressed by objects or equipment.

4. Exposure includes temperature extremes, contact with electric current, exposures to substances including animal venoms, and oxygen deficiencies, e.g., drowning.

\section{Prevention of Traumatic Injury Fatalities}

Most, if not all, occupational fatalities are preventable through hazard recognition and control, effective employee training, and appropriate selection and use of personal protective equipment. Some general guidance for prevention of traumatic injuries is given below. Guidance for specific hazards and training materials in both English and Spanish can be obtained free of charge through the internet addresses below. Many of the training documents are designed for tailgate training sessions. Many OSHA and NIOSH documents list recommended practices to reduce injury risks from specific landscape services hazards.

\section{General Guidance}

- Understand and comply with all OSHA regulations that apply to the landscape services operations and tasks.

- Develop, implement and enforce a comprehensive safety program that includes written rules and safe work procedures. A joint health and safety committee with employees $\&$ supervisors should be considered.

- Conduct an initial and daily jobsite survey before beginning work to identify all hazards and implement appropriate controls.

- Provide specific training for hazards such as power lines and other sources of electricity, tree trimming and felling, falls from heights, roadway vehicle operations, and hand and portable power tools use.

- Train operators of off-road machinery and other specialized equipment to follow manufacturers' recommended procedures for safe operation, service, and maintenance.

- Monitor workers during periods of high heat stress/strain and remind workers of the signs of heat-related illness and the need to consume sufficient water during hot conditions. 


\section{Specific Guidance for Landscape Services Hazards}

After Falling Into Landscaping Pond Hispanic Laborer Drowns, FACE Investigation Report, Oregon, www.cdc.gov/niosh/face/stateface/ or/03or008.html

Landscape Laborer Dies When the Tractor He is Driving Overturns, FACE Investigation Report, Colorado, www.cdc.gov/niosh/stateface/co/95094.html

Landscape Mowing Assistant Dies from Heat Stroke, FACE Investigation Report, Michigan, www.cdc.gov/niosh/stateface $/ \mathrm{mi} / 02 \mathrm{mi} 075 . \mathrm{html}$

Work-Related Roadway Crashes, Prevention Strategies for Employers www.cdc.gov/niosh/docs/2004-136/pdfs/2004-136.pdf

Preventing Falls and Electrocutions during Tree Trimming, NIOSH Alert www.cdc.gov/niosh/92-106.html

Tree Trimming and Removal Fact Sheet, U.S. OSHA

www.osha.gov/OshDoc/data_Hurricane_Facts/ trim.pdf

Tree Trimming and Removal Safety Tips, U.S. OSHA www.osha.gov/OshDoc/data_Hurricane_ Facts/tree_trimming_safety.pdf

\section{Free Tailgate Training Documents in English and Spanish}

OSHA PLANET Alliance Safety \& Health Topics Page www.osha.gov/SLTC/landscaping/index.html

California State Compensation Insurance Fund Bi-lingual Training www.scif.com/safety/safetymeeting/SafetyMtgTopics.asp

Farm Safety Association Inc. (Canada) www.fsai.on.ca/manuals/manual-landtips.pdf

Kansas State University Research and Extension and College of Agriculture, www.oznet.ksu.edu/library/Landscaping_Equipment_Safety.html

Ohio State Univ. College of Food, Agricultural \& Environmental Sciences, Landscape Worker Bi-lingual Training ohioline.osu.edu/aex-fact/192/index.html

Oregon Health and Science University, Center for Research on Occupational and Environmental Toxicology www.croetweb.com/links.cfm?subtopicID $=547$

PLANET Safety Tip Sheets www.landcarenetwork.org/cms/programs/safety.html
DEPARTMENT OF HEALTH AND HUMAN SERVICES

Centers for Disease Control and Prevention

National Institute for Occupational Safety and Health 4676 Columbia Parkway

Cincinnati, OH 45226-1998

To receive documents or other information about occupational safety and health topics, contact NIOSH at Telephone: 1-800-CDC-INFO (1-800-232-4636)

TTY: 1-888-232-6348

E-mail: cdcinfo@cdc.gov or visit the NIOSH Web site at www.cdc.gov/niosh.

For a monthly update on news at $\mathrm{NIOSH}$, subscribe to NIOSH eNews by visiting www.cdc.gov/niosh/eNews.

DHHS (NIOSH) Publication No. 2008-144

October 2008 